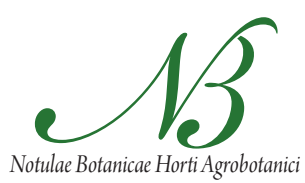

Cluj-Napoca

\title{
Volatile Compounds Determined by HS/GC-MS Technique in Peel and Pulp of Fig (Ficus carica L.) Cultivars Grown in Mediterranean Region of Turkey
}

\author{
Sadiye GOZLEKCI ${ }^{1 *}$, Ebru KAFKAS² Sezai ERCISLI ${ }^{3}$ \\ ${ }^{1}$ Akdeniz University, Faculty of Agriculture, Department of Horticulture, 07070 Antalya, Turkey; sgozlekci@akdeniz.edu.tr (*orresponding author) \\ ${ }^{2}$ Cukurova University, Faculty of Agriculture, Department of Horticulture, 01300 Adana, Turkey \\ ${ }^{3}$ Ataturk University, Faculty of Agriculture, Department of Horticulture, 25240 Erzurum, Turkey
}

\begin{abstract}
Aromatic profile of peels and pulps of four commercial fig cultivars ('Bursa Siyahi', 'Karabakunya', 'Sari Lop' and 'Sultan Selim') from Turkey were determined first time by using Headspace Gas Chromatogropy-Mass Spectrophotometer (HS/GC-MS) technigue. In general, aldehydes and therpenes were the major volatile group responsible aroma for peels and pulps in fig fruits. Total aldehydes were higher in pulps than peel in all cultivars. However total therpenes were higher in peel rather than in pulp. Among therpenes, $\beta$-caryophyllene were the major volatile compounds found in both peel and pulp. Phenol, 2,6-bis (1,1-dimethylethyl)-4-methyl were the second important group responsible for fig aroma presented in both peel and pulp. Among aldehydes, 2-hexanal were found in high proportion only in pulp in all cultivars. The other groups responsible fig aroma were 2-furancaboxaldehyde, 5 (hydroxymethyl), benzyaldethyde, furfural and Germacrene D. $\alpha$-curcumene, $\beta$-bisabolene and $\beta$-sesquiphellandrene were determined only in cv. 'Bursa Siyahi' peel and pulp and discriminated this cultivar from the others.
\end{abstract}

Keywords: fig, volatile compounds, flavour, GC-MS

\section{Introduction}

Figs (Ficus carica L.) are a widespread fruit species consumed both fresh and dried and commonly grown, especially in warm, dry climates. The world production of figs is over one million tons, and production mostly concentrated in the Mediterranean countries including Spain, Portugal, Algeria, Greece, Italy, Turkey, Morocco, Tunisia, Egypt (Gozlekci, 2010; Veberic et al., 2008).

For a long time, Turkey has been dominating world fig production average yearly 300,000 tons production and the country has also the biggest fig exporter among the producer countries with 180,000 tons of exports annually which represents $52 \%$ of the total world fig exports (FAO, 2007). The fig is widely grown and extended to the Marmara, Black Sea, South East Anatolia, the Aegean and the Mediterranean Regions in Turkey and the country is one of the most important diversity center for fig in the world (Bostan et al., 1997; Caliskan and Polat, 2008; Kuden and Tanriver, 1998; Simsek, 2011).

'Sari Lop' and 'Bursa Siyahi' are the dominant dried and fresh fig cultivars growth by farmers in Turkey. Dried fig exports of Turkey is concentrated only 'Sari Lop' cultivar (Aksoy et al., 1992). 'Bursa Siyahi' is one of the best quality fresh fig cultivar grown in the country and there is an increase interst for its production for export. In addition to Bursa Siyahi, there are many other good quality fresh fig cultivars in Turkey (Polat and Ozkaya, 2005).

The sensory characteristics of fruits can be loosely grouped into three categories: flavour, texture and appear- ance. Flavour, in particular, plays a major role in both selection and enjoyment of fruit, being perceived simultaneously through two human senses: taste and smell, where aroma is detected (Durán and Costell, 1999; Jiang and Zhang, 2010; Qiao et al., 2010).

Aromas are formed by volatile aromatic compounds, which are biosynthesized during the normal metabolic process in plants and which may be further modified by cooking or other processing (Orav and Khan, 2001)

Aroma is one of the most important quality attributes of fruits and the most significant parameter of quality in both eatable and processed products. In order to improve the fruit quality and modify the aroma formation, information on the flavor constitution present in fruit is needed and it is important for cultivar breeding and further processing (Kafkas et al., 2009; Minh et al., 2002).

Studies on devoted to volatile compounds involved in fig in world are very limited. Only a few studies conducted in different fig producer countries concerning the volatile fraction of fig showing a great variability concerning the nature and the concentration of the aroma compounds isolated from different cultivars are available (Gibernau $e t$ al., 1997; Grison et al., 1999; Oliveira et al., 2010). In these studies, it was indicated that therpenes mostly involved in the typical, basic fig flavour, whereas several compounds, like aldehydes, alcohols and ketones were described as contributors of aroma of different fig cultivars.

The aim of the present work was to characterize the aroma of fig cultivars using HS/GC-MS in order to identify volatile compounds. 
106

\section{Material and methods}

Four commercial fig cultivars ('Bursa Siyahi', 'Karabakunya', 'Sari Lop' and 'Sultan Selim') were harvested during the 2009 season at full maturity in Akdeniz University. 'Bursa Siyahi' and 'Karabakunya' has dark purple and 'Sari Lop' and 'Sultan Selim' has yellowish fruit skin color. Among them, 'Sari Lop' was dried cultivar and the rest of the cultivars were used for fresh consumption (Tab. 1). Totally 75 fruits per cultivar were harvested during commercial maturation stage and used for each cultivars with three replicate. Fresh fig peel and pulp were obtained from fruits for experimental and were used for analysis. Volatile compounds were determined both in peel and pulp of cultivars. Peel and pulp tissue was obtained from fresh fruits and homogenized with equal parts of deionized water and the diluted homogenate was stored at $-20^{\circ} \mathrm{C}$ until used for volatile determinations.

The juice were obtained from peel and pulp from approximately randomly selected twenty five fruits for each replicate and immediately mixed with $5 \mathrm{~g} \mathrm{NaCl}$ for $50 \mathrm{ml}$ of fruit juice.

Volatile compounds were analyzed on an HS/GC/ MS apparatus equipped with an HP-5 MS (30 m×0.25 $\mathrm{mm} \times 0.25 \mu \mathrm{m})$ fused-silica capillary column. Helium (1 $\mathrm{ml} / \mathrm{min}$ ) was used as a carrier gas. The SPME holder, for manual sampling, and fibres used in this study were purchased from Supelco (Bellefonte, PA). The polydimethylsiloxane (PDMS) $100 \mathrm{~mm}$ fibres were used and the fibres conditioned for $1 \mathrm{~h}$ at $240^{\circ} \mathrm{C}$ in the $\mathrm{GC}$ injector port before being used, and they were cleaned between analyses to prevent contamination. The injector temperature was $250^{\circ} \mathrm{C}$, set for split less injection. The oven conditions were set to $50^{\circ} \mathrm{C}$ for $1 \mathrm{~min}$ and then the temperature was increaseed to $200^{\circ} \mathrm{C}$ at a rate of $4^{\circ} \mathrm{C} / \mathrm{min}$. Thermal desorption was allowed for $1.5 \mathrm{~min}$. The detector temperature was $280^{\circ} \mathrm{C}$. The components were identified by comparison of mass spectra and retention time data with those of authentic samples and complemented with a Wiley and NIST GC-MS library (Shalit et al., 2001).

\section{Results and discussion}

We determined a total 24 volatile and semi-volatile compounds from peel and pulps of four commercial fig cultivars identified by HS/GC-MS. These 24 compounds were presented in four cultivars peel and pulps in different proportion (Tab. 2). The cultivars showed different profile patterns and in general pulp were found more diverse than peel. Oliveira et al. (2010) also reported that fig pulps had more diversity than peel in terms of volatile compounds which supports the present finding.

The determined volatiles were belongs to aldehydes ( 3 compounds), terpenes (11 compounds), esters (1 compound), alcohols (4 compounds), ketones (3 compounds) and other compounds (1). However, the aldehydes and terpenes were the major volatiles in terms of proportion in fig fruits in all cultivars (Tab. 2).

The cultivar 'Bursa Siyahi' had the highest number of volatile compounds in its peel (16) and followed by cv. 'Sari Lop' (14), 'Sultan Selim' (11) and cv. 'Karabakunya' (8), respectively. In pulp, cvs. 'Sultan Selim' and 'Sari Lop' had the highest equal number of volatile compounds (12) and followed by cvs. 'Bursa Siyahi' and 'Karabakunya' (11), respectively (Tab. 2).

The number of volatiles detected in fruits were the highest in pulp rather than peel in cultivars 'Karabakunya' and 'Sultan Selim' and were the highest in peel compared to pulp in cultivars 'Bursa Siyahi' and 'Sari Lop' (Tab. 2).

Among the aldehydes, 2-hexanal was the highest proportion. The aldehydes were 4-9 times higher in pulps rather than in peel in fruits of all cultivars (Tab. 2).

The content of terpenes is quite complex, if compared with that of fig peel and pulp (Tab. 1). Here too, the compounds have been grouped in two classes, namely monoterpenes and sesquiterpenes to render comparison of the cultivars easier. One monoterpene, hydrocarbon:

Tab. 1. Some important fruit characteristics of fig cultivars used in this study

\begin{tabular}{ccccc}
\hline \multirow{2}{*}{ Characteristics } & \multicolumn{4}{c}{ Cultivars } \\
\cline { 2 - 5 } & 'Bursa Siyahi' & 'Karabakunya' & 'Sari Lop' & 'Sultan Selim' \\
\hline Fruit weight $(\mathrm{g})$ & 90.40 & 42.98 & 67.25 & 45.88 \\
Fruit lenght $(\mathrm{mm})$ & 57.34 & 44.53 & 47.94 & 48.35 \\
Fruit diamete $(\mathrm{mm})$ & 53.57 & 42.28 & 54.49 & 42.64 \\
Fruit index $(\mathrm{Fd} / \mathrm{Fl})$ & 0.93 (oblong) & 0.95 (oblong) & 1.14 (oblate) & $0.88(\mathrm{oblong})$ \\
\hline Neck length $(\mathrm{mm})$ & 9.43 & 5.27 & 3.48 & 7.49 \\
Ostiole width $(\mathrm{mm})$ & 3.54 & 0.49 & 3.55 & 2.78 \\
Stalk lenght $(\mathrm{mm})$ & 3.16 & 3.62 & 2.91 & 5.52 \\
Titratable acidity $(\%)$ & 0.21 & 0.15 & 0.14 & 0.19 \\
Soluble solid Content $(\%)$ & 19.5 & 22.00 & 22.50 & 21.20 \\
Fruit cavity & Absent & Absent & Absent & Present \\
Fruit skin color & Purplish (green sectors around the neck) & Purplish black & Light yellow & Greenish yellow \\
Fruit internal color & Dark red & Dark red & Pink & Amber-pink \\
\hline
\end{tabular}

${ }^{*}$ Fruit weight, length, diameter, index, neck length, ostiole width and stalk length were determined in this study. Titratable acidity, soluble solid content, fruit cavity, fruit skin color and fruit internal color obtained from Anonymous (2001) 
Tab. 2. Volatile compositions (relative content, \%) of four fig (Ficus carica L.) cultivars

\begin{tabular}{|c|c|c|c|c|c|c|c|c|}
\hline \multirow{3}{*}{ Compounds } & \multicolumn{8}{|c|}{ Cultivars } \\
\hline & \multicolumn{2}{|c|}{ 'Karabakunya' } & \multicolumn{2}{|c|}{ 'Sultan Selim' } & \multicolumn{2}{|c|}{ 'Bursa Siyahi' } & \multicolumn{2}{|c|}{ 'Sari Lop' } \\
\hline & Pulp & Peel & Pulp & Peel & Pulp & Peel & Pulp & Peel \\
\hline \multicolumn{9}{|c|}{ Aldehydes } \\
\hline (E)-2-Hexanal & 20.07 & 1.77 & 20.08 & n.d. & 11.05 & n.d. & 16.39 & n.d. \\
\hline 2-Furancarboxaldehyde, 5 (hydroxymethyl) & 10.50 & 0.73 & 7.89 & n.d. & 5.96 & 2.95 & 13.59 & 4.56 \\
\hline Benzaldehyde & 8.45 & n.d. & 5.05 & 0.24 & 6.02 & 0.15 & 5.69 & n.d. \\
\hline Furfural & 3.15 & 2.56 & 1.06 & 3.65 & 0.30 & 2.59 & 3.19 & 6.59 \\
\hline Total aldehydes & 42.17 & 5.06 & 34.08 & 3.89 & 23.33 & 5.69 & 38.86 & 11.15 \\
\hline \multicolumn{9}{|c|}{ Terpenes } \\
\hline$\beta$-Caryophyllene & 37.45 & 48.65 & 32.07 & 37.33 & 17.25 & 22.38 & 15.98 & 21.15 \\
\hline Limonene & n.d. & 0.51 & n.d. & 0.35 & n.d. & n.d. & 0.59 & n.d. \\
\hline$\beta$-Cubebene & n.d. & 0.25 & 1.64 & 7.32 & n.d. & n.d. & 5.45 & 8.48 \\
\hline$\alpha$-Bergamotene & n.d. & 0.53 & n.d. & n.d. & n.d. & n.d. & n.d. & n.d. \\
\hline$\beta$-Selinene & n.d. & 0.61 & n.d. & 0.58 & n.d. & n.d. & n.d. & n.d. \\
\hline Germacrene D & 4.32 & 9.98 & 11.75 & 12.56 & n.d. & 5.06 & 5.76 & 9.19 \\
\hline$\alpha$-Humulene & n.d. & n.d. & 2.09 & 1.24 & n.d. & n.d. & n.d. & n.d. \\
\hline$(+)$-Sativene & n.d. & n.d. & n.d. & 1.19 & n.d. & n.d. & n.d. & n.d. \\
\hline$\alpha$-Curcumene & n.d. & n.d. & n.d. & n.d. & 8.15 & 5.87 & n.d. & n.d. \\
\hline$\beta$-Bisabolene & n.d. & n.d. & n.d. & n.d. & 7.15 & 2.75 & n.d. & n.d. \\
\hline$\beta$-Sesquiphellandrene & n.d. & n.d. & n.d. & n.d. & 5.02 & 2.55 & n.d. & n.d. \\
\hline Total terpenes & 41.77 & 60.53 & 47.55 & 60.57 & 37.57 & 38.61 & 27.78 & 38.82 \\
\hline \multicolumn{9}{|c|}{ Esters } \\
\hline Phthalic acid, diisobutyl ester & 1.91 & n.d. & 1.67 & n.d. & 9.25 & 0.48 & 3.25 & 0.96 \\
\hline Total esters & 1.91 & n.d & 1.67 & n.d. & 9.25 & 0.48 & 3.25 & 0.96 \\
\hline \multicolumn{9}{|c|}{ Alcohols } \\
\hline$\beta$-(Methylamino) ethanol & n.d. & n.d. & 1.17 & n.d. & n.d. & 6.05 & n.d. & 3.02 \\
\hline Furfuryl alcohol & n.d. & n.d. & n.d. & n.d. & 0.32 & n.d. & 0.98 & 2.25 \\
\hline Total alcohols & & & 1.17 & & 0.32 & & 0.98 & 2.25 \\
\hline \multicolumn{9}{|c|}{ Acids } \\
\hline n-Nonanoic acid & n.d. & n.d. & n.d. & 1.34 & 0.36 & n.d. & n.d. & n.d. \\
\hline Acetic acid & n.d. & n.d. & n.d. & n.d. & 2.25 & n.d. & 0.56 & 4.69 \\
\hline Total acids & & & & 1.34 & 2.61 & & 0.56 & 4.69 \\
\hline \multicolumn{9}{|c|}{ Ketones } \\
\hline 2,3-Dihydro-3,5-dihydroxy-6-methyl-4-pyrone & n.d. & 0.17 & n.d. & 1.90 & 4.47 & n.d. & 1.90 & 2.96 \\
\hline Dihydroxyacetone & n.d. & n.d. & n.d. & n.d. & 3.20 & n.d. & 2.56 & 5.26 \\
\hline Dihydro-4-hydroxy-2(3H)-furanone & n.d. & n.d. & n.d. & n.d. & 0.51 & n.d. & n.d. & n.d. \\
\hline Total ketones & & 0.17 & & 1.90 & 8.18 & & 4.46 & 8.22 \\
\hline \multicolumn{9}{|c|}{ Other compounds } \\
\hline Phenol, 2,6-bis(1,1-dimethylethyl)-4-methyl & 8.56 & 18.25 & 10.25 & 15.99 & 9.18 & 39.98 & 9.92 & 15.47 \\
\hline Others & 5.59 & 15.99 & 5.28 & 16.31 & 9.56 & 9.19 & 14.19 & 15.42 \\
\hline
\end{tabular}

limonene has been identified. Limonene almost negligible (none of were excesses 1\%) was detected only in pulp in cvs. 'Karabakunya' and 'Sultan Selim' and in peel in cv. 'Sari Lop'. Cultivar 'Bursa Siyahi' peel and pulp did not contain Limonene (Tab. 2). The cultivar 'Sari Lop' had the lowest content of sesquiterpenes.

$\beta$-Caryophyllene was the dominant sesquiterpene represented nearly equal proportion in both peel and pulp of all fig cultivars. This compound have been reported as antibacterial properties (Kim et al., 2008). The second important terpene was Germacrene-D in fig peel and pulps.
Germacrene-D was found high percentage in white fig cultivars (cvs. 'Sari Lop' and 'Sultan Selim') (Tab. 2). This sesquiterpene did not found in pulp of cv. 'Bursa Siyahi' (Tab. 2). Previous studies indicated that Germacrene-D is the one of the main volatile compounds for white fig cultivars (Oliveira et al., 2010; Steliopoulos et al., 2002).

On the other hand, $\alpha$-Curcumene, $\beta$-Bisabolene and $\beta$-Sesquiphellandrene were determined only in cv. 'Bursa Siyahi' peel and pulp and discriminated this cultivar from the others and could be used as chemical marker for this cultivar (Tab. 2). 
108

The peel of 'Karabakunya' and 'Sultan Selim' did not include esters. Alcohols and ketones found in small proportion in all fig fruits (Tab. 2).

Among volatile compounds, 2-furancaboxaldehyde, 5 (hydroxymethyl), furfural as aldehydes; $\beta$-cubenene, $\beta$-selinene, $\alpha$-humulene, $(+)$-sativene, $\alpha$-curcumene, $\beta$-bisabolene, $\beta$-sesquiphellandrene as therpenes; phthalic acid, diisobutyl ester as ester; $\beta$-(methylamino) ethanol and furfuryl as alcohol; n-nonanoic acid and acetic acid as acids; 2,3-dihydro-3,5-dihydroxy-6-methyl-4-pyrone, dihydroxyacetone and dihydro-4-hydroxy- $2(3 \mathrm{H})$-furanone as ketones are reported and limited data were enhanced related to fig flavour (Tab. 2).

The rest of the volatile compounds has bee already reported in fig fruits (Grison-Pige et al., 2002; Oliveria $e t$ al., 2010).

\section{Conclusions}

Differences perceived among the four cultivars studied are related to the quantities of 24 volatiles identified as key aroma compounds by the HS/GC-MS analysis. These compounds could be used as tracers to characterize and discriminate fig cultivars on aromatic criteria. The cultivar 'Bursa Siyahi' showed distinct aroma pattern compared the rest of cultivars. It is still premature to establish if some kind of exploitation of these volatile components is feasible, for example in the fig field; further studies are necessary to include more cultivars comprising the yellow, green, purple, brown and black skin colored fig cultivars, as well as the application of alternative extraction methodologies.

\section{References}

Aksoy U, Seferoglu G, Misirli A, Kara S, Duzbastilar M, Bulbul S, Can HZ, Sahin N (1992). Clonal selection in cv. 'Sari Lop' fig. Processing $1^{\text {st }}$ National Horticultural Congress 1:545-548, Izmir. (in Turkish).

Anonymous (2001). Fig cultivars. Ministry of Agriculture. TUGEM. 83, Ankara.

Bostan SZ, Islam A, Aygun AA (1979). A study on pomological caracteristics of local fig cultivars in Northern Turkey. Acta Hort 480:71-73.

Caliskan O, Polat AA (2008). Fruit characteristics of table fig (Ficus carica) cultivars in subtropical climate conditions of the Mediterranean region. Sci Hortic 115:360-367.

Durán L, Costell E (1999). Review perception of taste. Physiochemical and psychophysical aspects. Food Sci Tech Int 5:299-309.

FAO (2007). http://www.fao.org/statisticaldatabase/updated: 02 September 2010.

Gibernau M, Buser HR, Frey JE, Hossaert-McKey (1997). Volatile compounds from extracts of figs of Ficus carica. Phytochemistry 46:241-244.
Gozlekci S (2010). Selection studies on fig (Ficus carica L.) in Antalya province of Turkey. Afr J Biotech 9:7857-7862.

Grison L, Edwards AA, Hossaert-McKey M (1999). Interspecies variation in floral fragrances emitted by tropical Ficus species. Phytochemistry 52:1293-1299.

Grison-Pigé L, Hossaert-McKey M, Greeff JM, Bessière JM (2002). Fig volatile compounds- A first comparative study. Phytochemistry 61:61-71.

Jiang B, Zhang ZW (2010). Volatile compounds of young wines from Cabernet Sauvignon, Cabernet Gernischet and Chardonnay varieties grown in the Loess Plateau Region of China. Molecules 15:9184-9196.

Kafkas E, Ercisli S, Koc NK, Baydar K, Yilmaz H (2009). Chemical composition of blood orange varieties from Turkey: A comparative study. Phycog Mag 5:329-335.

Kim YS, Park SJ, Lee EJ, Cerbo RM, Lee SM, Ryu CH, Kim G, Kim J, Ha Y (2008). Antibacterial compounds from rose bengal-sensitized photooxidation of $\beta$-caryophyllene. J Food Sci 73:540-545.

Kuden AB, Tanriver E (1998). Plant genetic resources and selection studies on figs in the east Mediterranean and south east Anatolia regions. Acta Hort 480:49-54.

Minh Tu NT, Thanh LX, Une A, Ukeda H, Sawamura M (2002). Volatile constituents of Vietnamese pummelo, orange, tangerine and lime peel oils. Flavour Frag J 17:169174.

Oliveira AP, Silva LR, de Pinho PG, Gil-Izquierdo A, Valentão P, Silva BM, Pereira JA, Andrade PB (2010). Volatile profiling of Ficus carica varieties by HS-SPME and GC-IT-MS. Food Chem 123:548-557.

Orav A, Kann J (2001). Determination of peppermint and orange aroma compounds in food and beverages. Proc Estonian Acad Sci Chem 50:217-225.

Polat A, Ozkaya M (2005). Selection studies on fig in the Mediterranean Region of Turkey. Pak J Botany 37:567-574

Qiao Y, Xie BJ, Zhang Y, Fan G, Yao XL, Pan SY (2010). Characterization of aroma active compounds in fruit juice and peel oil of Jinchen sweet orange fruit (Citrus sinensis (L.) osbeck) by GC-MS and GC-O. Molecules 13:1333-1344.

Shalit M, Katzir N, Tadmor N, Larkov O, Burger Y, Shalekhet N, Lastochkin E, Ravid U, Amar O, Edelstein M, Karchi Z, Lewinsohn E (2001). Acetyl Co-A: Alcohol acetyl transferase activity and aroma formation in ripening melon fruits. J Agric Food Chem 49:794-799.

Simsek M (2011). A study on selection and identification of table fig types in east edge of Firat River. Asian J Animal Vet Adv 6:265-273.

Steliopoulos P, Wust M, Adam KP, Mosandl A (2002). Biosynthesis of the sesquiterpene germacrene $\mathrm{D}$ in Solidago canadensis: ${ }^{13} \mathrm{C}$ and ${ }^{2} \mathrm{H}$ labeling studies, Phytochemistry 60:13-20.

Veberic R, Colaric M, Stampar F (2008). Phenolic acids and flavonoids of fig fruit (Ficus carica L.) in the northern Mediterranean region. Food Chem 106:153-157. 